\title{
Evaluasi Hasil Pelatihan Karyawan Terhadap Kinerja Karyawan (Studi Kasus PT. Bank Bukopin)
}

\author{
Firstianty Wahyuhening Fibriany ${ }^{1}$, Nur Hani Oktaviani ${ }^{2}$ \\ Universitas Bina Sarana Informatika \\ ${ }^{1}$ firstianty.fbr@bsi.ac.id \\ 2 nurhanioktaviani@gmail.com
}

\begin{abstract}
ABSTRAK
Sumber daya manusia merupakan aset penting yang dimiliki oleh setiap perusahaan. Sumber daya manusia yang unggul dan profesional dalam pekerjaannya akan dapat menigkatkan kinerja perusahaan. Untuk mendapatkan karyawan yang unggul dan profesional dalam pekerjaannya, salah satu usaha yang dapat dilakukan perusahaan adalah dengan memberikan pelatihan bagi karyawan agar kinerja karyawan sesuai dengan keinginan perusahaan. Berdasarkan permasalah tersebut, maka penelitian ini bertujuan untuk mendapatkan hasil pelatihan, hasil kinerja dan mengevaluasi pelatihan yang diberikan apakah ada pengaruhnya terhadap kinerja karyawan. Penelitian ini menggunakan data kuantitatif dengan menggunakan kuesioner sebagai pengumpulan data primernya. Pengumpulan sampel data untuk penelitian ini adalah dengan teknik probability sampling, yaitu teknik pengambilan sampel yang memberikan peluang yang sama dalam populasi untuk dipilih menjadi sampel. Lembaran kuesioner disebarkan kepada karyawan PT. Bank Bukopin Jakarta. Pada uji koefisen korelasi, mendapatkan nilai 0,338. yang artinya hubungan antara variabel $\mathrm{X}$ dan $\mathrm{Y}$ lemah. Pada uji regresi sederhana diperoleh hasil perhitungan yang menunjukkan bahwa $\mathrm{Y}=19,544+0,396 \mathrm{X}$. Selanjutnya uji Anova (Uji F) diperoleh hasil 4,890 > 2,84 yang berarti Ho ditolak dan Ha diterima. Dapat dikatakan bahwa dalam penelitian ini terdapat adanya pengaruh antara pelatihan terhadap kinerja karyawan.
\end{abstract}

Kata Kunci : Sumber Daya Manusia, Pelatihan, Kinerja, Evaluasi Pengaruh

\section{ABSTRACT}

Human resources are an important asset that belongs to every company. A superior human resources professional in his job and will be able to improve the company's performance. To get a superior and professional employees in her work, one of the company's business that can be done is to provide training for employees in order for the performance of employees in accordance with the wishes of the company. Based on the problem, then this study aims to get results training, performance results and evaluate training provided if there is its effect on the performance of employees. These studies use quantitative data by using the questionnaire as a primary data collection. The collection of sample data for this research is with the technique of sampling probability sampling techniques, i.e., that gives the same opportunities in the population to be selected into the sample. Sheet of the questionnaire disseminated to employees of PT. Bank Bukopin Jakarta. On the test of the correlation koefisen, get the value of 0.338. which means the relationship between variables $X$ and $Y$ are weak. A simple regression test on the obtained results of calculation show that $Y=19.544+0,396 X$. Next test Anova ( $F$ Test) obtained results 4.890 > 2.84 meaning Ho denied and Ha is received. It can be said that in this study, there is the presence of influence between training on performance of employees.

Keywords: Human Resources, Training, Performance, Evaluation Of Influence

Naskah diterima: 30 Juli 2019, direvisi: 12 Agustus 2019, diterbitkan: 16 September 2019

ISSN: 2355-0295, e-ISSN: 2549-8932

http://ejournal.bsi.ac.id/ejurnal/index.php/ecodemica 


\section{PENDAHULUAN}

Persaingan yang terjadi pada industri perbankan membuat perusahaan harus menyiapkan karyawannya secara baik. Sumber Daya Manusia (SDM) dengan kualitas yang unggul dan profesional sangat penting dan sangat dibutuhkan perusahaan untuk menjalankan kegiatan perusahaan dan mencapai tujuan yang telah ditetapkan perusahaan sesuai dengan visi dan misinya agar dapat tercapai produktivitas perusahaan secara maksimal.

Untuk mengantisipasi dan juga menghadapi persaingan pada indutri perbnkan tersebut, perlu dilakukan kegiatan peningkatan sumber daya manusia secara optimal. Salah satu cara yang dapat dilakukan untuk meningkatkan SDM perusahaan adalah dengan menyelenggarakan pelatihan terhadap karyawannya.

Kegiatan pelatihan karyawan adalah sebagai sarana untuk meningkatkan kemampuan, keterampilan, pengetahuan umum serta keahlian pada bidang dan tugas para karyawan (Prasetyo \& Relawan, 2017). Kinerja karyawan perlu dikembangkan dan dijaga untuk menghasilkan kualitas dan kuantititas yang baik. Hasil dari pelatihan yang diberikan perusahaan kepada karyawan diharapkan dapat merubah kinerja karyawan menjadi lebih baik, yang dapat dilihat pada hasil perkerjaan yang dilakukan oleh setiap karyawan melalui penilaian kinerja ataupun hasil yang terlihat setiap hari.

Setiap karyawan dituntut agar dapat bekerja secara efektif dan efisien dengan hasil kualitas dan kuantitas kinerja karyawan yang baik sehingga perusahaan dapat bersaing dengan maksimal. Kinerja merupakan hasil yang diperoleh oleh suatu organisasi yang dihasilkan selama satu periode waktu menurut (Fahmi, 2016) dalam (Fibriany, 2017)

PT. Bank Bukopin merupakan salah satu bank swasta nasional yang sangat memperhatikan peningkatan kinerja karyawan nya. Untuk mencapai peningkatan kinerja tersebut, salah satu cara yang dignakannya adalah dengan melakukan pelatihan terhadap karyawan. PT. Bank Bukopin juga ingin mengevaluasi pengaruh terhadap pelatihan yang diselenggarakannya, apakah pelatihan yang diberikan akan memberikan pengaruh positif atau tidak terhadap peningkatan kinerja karyawannya tersebut. Untuk itu, penelitian ini oleh penulis akan dilihat dan diukur pengaruh pelatihan yang diberikan oleh perusahaan terhadap kinerja karyawan.

Berdasarkan latar belakang yang telah diuraikan sebelumnya, maka penulis dapat menuliskan pada perumusan masalah dalam bentuk hipotesis (Sujarweni, 2015). Hipotesis yang akan diteliti adalah:

Ha: Terdapat pengaruh pada program pelatihan terhadap kinerja karyawan di PT. Bank Bukopin Ho: Tidak terdapat pengaruh pada program pelatihan terhadap kinerja Karyawan di PT. Bank Bukopin

\section{KAJIAN LITERATUR}

Pelatihan Karyawan

Pelatihan karyawan menurut Sastradipoera (2006:122) dalam (Jayanthi \& Cahyana, 2014) adalah salah satu proses pendidikan jangka pendek yang menggunakan prosedur yang sistematik dan terorganisasi yang dengan prosedur itu personalia nonmenejerial belajar pengetahuan dan keterampilan teknis untuk mencapai tujuan tertentu.

Sedangkan menurut (Sedarmayanti, 2016) mengatakan bahwa "pelatihan merupakan usaha mengurangi atau menghilangkan terjadinya kesenjangan antara kemapuan karyawan dengan yang dikehendaki organisasi"

Berdasarkan kedua pengertian di atas, maka pelatihan merupakan suatu proses yang dilakukan untuk menambah pengetahuan dan mengurangi kesejangan kemampuan karyawan dalam bekerja yang diharapkan dapat meningkatkan produktivitas ataupun kinerja dari karyawan tersebut.

Tujuan Pelatihan

Tujuan pelatihan menurut Sedarmayanti (2016) dalam (Fibriany, 2017) adalah terdapat 2 tujuan pelatihan, yaitu tujuan umum dan tujuan khusus. Tujuan umum dari pelatihan adalah meningkatkan produktivitas sesuai dengan tujuan organisasi. Sedangkan tujuan khususnya adalah:

1. Kualitas kerja karyawan

2. Produktivitas kerja

3. Mutu perencanaan tenaga kerja

4. Meningkatkan semangat dan moral kerja

5. Kesehatan dan Keselamat Kerja Karyawan dan Organisasi

6. Mencegah kadaluarsa pengetahuan dan keterampilan yang dimiliki karyawan

7. Pengembangan diri karyawan

Manfaat Pelatihan

Manfaat pelatihan menurut Veithzal Rivai (2004:231) dalam (Jayanthi \& Cahyana, 2014) adalah sebagai berikut:

1. Manfaat untuk karyawan 
a. Membantu karyawan dalam membuat keputusan dan pemecahan masalah yang efektif

b. Melalui pelatihan dan pengembangan, veriabel pengenalan, pencapaian, prestasi, pertumbuhan, tanggung jawab, dan kemajuan dapat diinternalisasi dan dilaksanakan

c. Membantu dan mendorong mencapai pengembangan diri dan rasa percaya diri

d. Membantu karyawan mengatasi stress, tekanan kerja, frustasi dan konflik

e. Memberikan informasi tentang meningkatnya pengetahuan kepemimpinan, keterampilan komunikasi dan sikap

f. Membantu karyawan mendekati tujuan pribadi sementara meningkatkan keterampilan interaksi

2. Manfaat untuk perusahaan

a. Mengarahkan untuk meningkatkan profitabilitas atau sikap yang lebih positif terhadap rientasi profit

b. Memperbaiki pengetahuan kerja dan keahlian pada semua level perusahaan

c. Membantu karyawan untuk mengetahui tujuan perusahaan

d. Membantu untuk menciptakan image perusahaan yang lebih baik

e. Membantu mengembangkan perusahaan

f. Meningkatkan hubungan antara atasan dan bawahan

g. Membantu pengembangan promosi dari dalam

h. Membantu menekan biaya dalam berbagai bidang seperti produksi, SDM, dan administrasi

i. Membantu karyawan untuk menyesuaikan diri dengan perubahan

Langkah Penyusunan Program Pelatihan

Menurut (Sedarmayanti, 2016) agar penyusunan program pelatihan sesuai dengan tujuan yang akan diwujudkan, penyusunan program pelatihan harus dilakukan dengan sistematis. Langkah-langkah penyusunan dalam mengorganisasikan program pelatihan yang dapat dilakuakn antara lain dengan:

1. Melakukan penelitian dan pengumpulan data tentang aspek obyek yang akan dikembangkan

2. Menentukan materi

3. Menentukan metode pelatihan

4. Memilih pelatih sesuai kebutuhan

5. Mempersiapkan fasilitas yang dibutuhkan

6. Memilih peserta

7. Melaksanakan program

8. Melakukan evaluasi program
Jenis dan Metode Pelatihan

Menurut (Sedarmayanti, 2016) pelatihan bagi para karyawan atau pegawai di suatu organisasi atau institusi biasanya dikelompokkan menjadi dua, yakni:

1. Pelatihan pra-jabatan (pre-service training) Pelatihan ini diikuti oleh para pegawai baru atau calon pegawai baru di suatu institusi atau organisasi. Tujuan utama pelatihan ini memberika wawasan kepada para pegawai baru tersebut terhadap organisasi atau institusi tempat mereka bekerja. Melalui pelatihan ini para pegawai baru akan mengenal dan memahmi visi, misi, dan budaya kerja (corporate culture) organisasi sehingga dapat bekerja dengan baik, loyal dan penuh dedikasi.

2. Pelatihan dalam jabatan (in service training).

Pelatihan ini ditujukan kepada karyawan yang sudah bekerja di berbagai unit atau devisi dari suatu organisasi atau institusi. Tujuan pelatihan ini adalah untuk meningkatkan kinerja karyawan. Pelatihan dalam jabatan ini dibedakan menjadi dua, yaitu:

a. Pelatihan di luar tugas (off the job side training)

Karyawan sebagai peserta pelatihan keluar sementara dari kegiatan, tugas atau pekerjaanya. Kemudian mengikuti pelatihan dengan teknik belajar mengajar seperti lazimnya. Pada umumnya metode ini mempunyai dua macam teknik, yaitu:

1) Teknik presentasi informasi

Teknik ini menyajikan informasi yang tujuannya mengintroduksi kemampuan, pengetahuan, sikap dan keterampilan baru kepada para peserta. Yang termasuk kedalam teknik ini adalah:

a) Ceramah biasa

b) Teknik diskusi

c) Teknik pemodelan perilaku (behaviour modeling)

d) Teknik magang

2) Metode-metode simulasi

Simulasi adalah suatu peniruan karakteristik atau perilaku tertentu dari dunia rill sedemikian rupa sehingga, para peserta pelatihan dapat merealisasikan seperti keadaan sebenarnya. Maka peserta pelatihan akan mampu mempraktikkan apa yang telah disimulasikan. metode simulasi ini mencakup: 

a) Business game (permainan peran dalam bisnis)
b) Vestibule (pelatihan beranda)
c) Laboratory training (pelatihan dengan peralatan laboraturium)

3) Pelatihan dalam pekerjaan (on the job training)

(Sedarmayanti, 2016) mengatakan bahwa On the job training adalah pelatihan dimana pegawai baru atau yang belum berpengalaman belajar dengan pertama mengamati teman kerjanya atau manajer yang melakukan pekerjaan dan selanjutnya berusaha meniru perilaku mereka. Pembelajaran terfokus dan biasanya lebih cepat, karena instruktur dan peserta terlibat dalam produksi yang sebenarnya dan menggunakan peralatan dan materi yang sebenarnya dari pekerjaan langsung. Yang termasuk dalam metode ini adalah:
a) Coaching
b) Mentoring
c) Penugasan understudy

Keuntungan Pelatihan

Adapun keuntungan pelatihan menurut (Hartati \& Amir, 2016) bagi karyawan maupun perusahaan setelah mengikuti pelatihan sebagai berikut:

\section{Akan memiliki kemampuan}

Setelah mengikuti pelatihan, karyawan akan memiliki kemampuan untuk melakukan pekerjaan yang diberikan kepadanya.

2. Sikap dan mental karyawan

Dalam pelatihan, karyawan juga dilatih untuk menanamkan sikap mental karyawan menjadi positif dan lebih baik. Karyawan dapat bekerja keras dan tidak mudah putus asa.

a. Kerja sama

Di lembaga pelatihan karyawan dibentuk agar dapat bekerja sama antar teman dan saling menghargai.

b. Disiplin kerja

Karyawan yang mengikuti pelatihan juga diajarkan tentang disiplin dalam hal waktu kerja seperti jam masuk kerja, mengerjakan pekerjaan sampai tuntas dan mengikuti jam pulang kerja sesuai aturan yang ditetapkan.

c. Perilaku karyawan
Pelatihan juga mampu mengubah pandangan atau perilaku karyawan ke arah yang lebih positif sesuai aturan perusahaan.

d. Jenjang karir

Dengan melalui pelatihan calon karyawan akan dapat menentukan jenjang karirnya ke depan, terkadang pelatihan sebagai salah satu cara untuk meningkatkan jenjang karir agar dapat dipertimbangkan.

e. Loyalitas dan rasa memiliki

Dengan mengikuti pelatihan juga akan meningkatkan loyalitas calon karyawan kepada perusahaan. Sehingga akan bersungguh-sungguh dalam bekerja di perusahaan.

f. Pengetahuan baru

Di dalam pelatihan semua informasi akan diberikan, sehingga semakin sempurna pengetahuan yang diperoleh calon karyawan untuk menyelesaikan pekerjaanya.

\section{Kinerja}

Kinerja adalah tentang melakuka pekerjaan dan hasil yang dicapai dari pekerjaan tersebut, tentang apa yang dikerjakan dan bagaimana cara mengerjakannya (Wibowo, 2017).

Dilanjutkan oleh (Fahmi, 2016) kinerja karyawan mencerminkan pada proses tingkatan pencapaian hasil dengan diterapkanya keterampilan, kemampuan serta pengetahuan yang dimiliki karyawan. Dari hasil kinerja karyawan tersebut dapat dilihat pada kuantitas dan kualitas produktivitasnya. Kinerja juga dapat dikatakan sebagai suatu perbuatan, prestasi dan kontribusi karyawan dalam mengerjakan tugas-tugas yang diberikan oleh perusahaan.

Menurut (Fahmi, 2016) ada delapan dimensi perilaku dalam kinerja pegawai yaitu:

1. Kemampuan tugas spesifik

Seberapa baik pegawai dapat melakukan tugas yang merupakan persyaratan teknis utama dari suatu pekerjaan dan yang membedakan suatu pekerjaandari pekerjaan lainnya.

2. Kemampuan tugas yang tidak spesifik pekerjaan

Seberapa baik bagi pegawai dapat melakukan tugas yang tidak khusus untuk pekerjaan itu, namun diperlukan oleh kebanyakan atau sebagian besar pekerjaan di dalam organisasi.

3. Komunikasi lisan 
Seberapa baik pegawai dapat menulis atau berbicara dengan orang lain atau sekelompok orang.

4. Menunjukkan usaha

Seberapa besar orang berkomitmen terhadap tugas pekerjaannya dan seberapa itensif seorang pegawai melakukan tugas pekerjaanya.

5. Memelihara disiplin pribadi

Seberapa besar seorang pegawai menghindari perilaku negatif, seperti penyalah gunaan obat, alkohol, melanggar aturan, mangkir.

6. Memfasilitasi kinerja tim dan rekan kerja

Seberapa baik pegawai mendukung, membantu dan mengembangkan rekan kerjanya dan membantu sebuah tim atau kelompok yang berfungsi sebagai kesatuan yang efektif.

7. Supervisi

Seberapa baik seseorang mempengaruhi pegawai dalam interaksi tatap muka.

8. Manajemen dan administrasi

Seberapa baik seseorang menjalankan fungsi lain manajemen yang bukan bersifat mengawasi, seperti menetapkan tujuan, mengorganisasi orang dan sumber daya, memantau kemajuan, mengendalikan biaya dan mencari sumber daya tambahan.

\section{METODE PENELITIAN}

Untuk menemukan jawaban penelitian yang berjudul "Evaluasi hasil pelatihan terhadap kinerja karyawan", yang sesuai dengan rumusan masalah dan tujuan penelitian, maka digunakan metode penelitian deskriptif dengan pendekatan kuantitatif. Menurut Arikunto (2002:86) dalam (Jayanthi \& Cahyana, 2014) menyatakakan bahwa: "Metode Deskriptif adalah metode penelitian yang digunakan dalam mengkaji permasalahan-permasalahan yang terjadi saat ini atau masa sekarang". Tujuan dari penelitian deskriptif ini adalah untuk membuat deskripsi hubungan antarfenomena yang diselidiki. Metode deskriptif ini didukung dengan melakukan uji kuantitatif dengan menggunakan uji pengaruh (hipotesis) yang nantinya akan menghasilkan diterima atau ditolak berdasarkan perhitungan matematika dan statistik dengan menggunakan program SPSS ver 22.0.

Uji pengaruh dengan menggunakan program SPSS ver 22.0 ini akan mengevaluasi apakah terdapat pengaruh satu variabel terhadap variabel yang lain, yaitu pelatihan karyawan yang diberikan perusahaan terhadap kinerja karyawan tersebut.
Ruang lingkup penelitian ini hanya akan mengevaluasi pengaruh pemberian pelatihan untuk karyawan yang sedang melakukan pelatihan pada PT. Bank Bukopin.

Jenis data yang digunakan dalam penelitian ini adalah data primer kuantitatif yang bersumber dari pengisian kuisioner yang disebarkan pada karyawan yang sedang mengikuti pelatihan.

Sumber data yang digunakan adalah data primer dan data sekunder. Data primer diperoleh dari kuisioner dengan mengisi dan menjawab kuisioner yang diberikan peneliti kepada karyawan mengenai topik penelitian yang akan dibahas, yaitu pelatihan terhadap kinerja yang didukung dengan melakukan wawancara sebagai penegasan terhadap isian yang diberikan kepada karyawan.

Metode pengumpulan sampel data untuk penelitian ini adalah dengan teknik probability sampling yaitu teknik pengambilan sampel yang memberikan peluang yang sama dalam populasi untuk dipilih menjadi sampel (Prasetyo \& Relawan, 2017). Namun, karena kondisi lapangan yang tidak memungkinkan pengambilan sampel jenuh, maka penelitian ini menggunakan pengambilan sampel dengan menggunakan rumus slovin (Sujarweni, 2015). Jumlah sampel dalam penelitian ini diambil sebanyak 40 responden berdasarkan rumus slovin dengan pengambilan batas toleransi eror dilakukan sebesar 10\% untuk mengurangi dan meminimalisir terjadinya kesalahan dalam menjawab kuisioner akibat kurang pahamnya respoden dalam menjawab pertanyaan yang diberikan.

Hipotesis pada penelitian ini adalah bahwa pelatihan yang diselenggarakan oleh PT Bank Bukopin, akan mempengaruhi kinerja karyawan tersebut. Penelitian menggunakan hipotesis ini juga dilakukan oleh (Jayanthi \& Cahyana, 2014) untuk melihat pengaruh pelatihan dan kinerja di PT KAI Bandung.

Hipotesis yang dilakukan pada penelitian kali ini dibangun dengan asumsi bahwa kemampuan karyawan, sikap dan mental karyawan, kerjasama, perilaku karyawan, loyalitas karyawan, jenang karir, dan pengetahuan akan mempengaruhi kemampuan tugas spesifik dan tidak spesifik, komunikasi, usaha meningkatkan diri, kedisiplinan, motivasi, supervisi, dan manajemen administrasi.

\section{PEMBAHASAN}

Pelatihan yang dimaksud di dalam penelitian ini adalah hasil dari pelatihan yang diperoleh karyawan PT. Bank Bukopin Tbk (kantor pusat) 
yang dilakukan oleh penyelenggara pelatihan perusahaan. Responden yang dilibatkan adalah karyawan PT Bank Bukopin Tbk. (Kantor Pusat) Jakarta dengan jumlah karyawan sebanyak 65 orang berdasarkan. 65 orang ini untuk selanjutnya disebut dengan populasi.

Uji Instrumen Penelitian

Pengujian terhadap hasil instrumen penelitian ini dilakukan dengan menggunakan uji validitas dan uji reliabilitas. Pengujian ini variabel dependen dan independen. Variabel dependen di simbolkan dengan variabel $\mathrm{X}$, yaitu pelatihan, sedangkan variabel independen di simbolkan dengan variabel $\mathrm{Y}$, yaitu kinerja.

Variabel X diuraikan menjadi pertanyaan sebagai berikut:

Tabel 1.

Variabel X

\begin{tabular}{|c|c|c|}
\hline No & Variabel & Pernyataan \\
\hline 1 & $\begin{array}{c}\text { Memiliki } \\
\text { kemampuan }\end{array}$ & $\begin{array}{l}\text { Pelatihan meningkatkan } \\
\text { kemampuan dalam } \\
\text { menyelesaikan pekerjaan } \\
\text { dengan baik }\end{array}$ \\
\hline 2 & & $\begin{array}{l}\text { Karyawan mengetahui } \\
\text { cara untuk mencapai } \\
\text { target dengan tepat waktu }\end{array}$ \\
\hline 3 & $\begin{array}{l}\text { Sikap dan } \\
\text { mental } \\
\text { karyawan }\end{array}$ & $\begin{array}{l}\text { Karyawan diberikan cara } \\
\text { bagaimana mengelola } \\
\text { emosi dalam bekerja, } \\
\text { sikap positif, integritas } \\
\text { serta cara mengahadapi } \\
\text { orang lain dengan emosi } \\
\text { cerdas }\end{array}$ \\
\hline 4 & Kerja Sama & $\begin{array}{l}\text { Karyawan mengetahui } \\
\text { bagaimana cara } \\
\text { membangun team work } \\
\text { yang baik demi mencapai } \\
\text { tujuan bersama }\end{array}$ \\
\hline 5 & & $\begin{array}{l}\text { Karyawan dapat menjaga } \\
\text { hubungan dan } \\
\text { berkomunikasi dengan } \\
\text { baik dalam team work }\end{array}$ \\
\hline 6 & $\begin{array}{l}\text { Perilaku } \\
\text { Karyawan }\end{array}$ & $\begin{array}{l}\text { Karyawan mengetahui } \\
\text { aturan dan kebijakan- } \\
\text { kebijakan yang berlaku di } \\
\text { perusahaan }\end{array}$ \\
\hline 7 & Jenjang Karir & $\begin{array}{l}\text { Program pelatihan yang } \\
\text { diberikan sesuai dengan } \\
\text { jabatan karyawan yang } \\
\text { memperolehnya }\end{array}$ \\
\hline
\end{tabular}

\begin{tabular}{ccl}
8 & $\begin{array}{c}\text { Loyalitas } \\
\text { Karyawan }\end{array}$ & $\begin{array}{l}\text { Karyawan memiliki rasa } \\
\text { tanggung jawab atas } \\
\text { pekerjaan yang dilakukan } \\
\text { di perusahaan }\end{array}$ \\
\hline $\mathbf{9}$ & Pengetahuan & $\begin{array}{l}\text { Mendapatkan pengetahuan } \\
\text { baru yang sebelumnya } \\
\text { belum pernah } \\
\text { diketahui/dimengerti }\end{array}$ \\
& &
\end{tabular}

Sumber: (Jayanthi \& Cahyana, 2014)

Sedangkan variabel Y, Pertanyaan tersebut dituangkan dalam tabel sebagai berikut:

Tabel 2

Variabel Y

No Variabel Pertanyaan

\begin{tabular}{|c|c|c|}
\hline 1 & $\begin{array}{c}\text { Kemampuan } \\
\text { tugas spesifik } \\
\text { pekerjaan }\end{array}$ & $\begin{array}{l}\text { Karyawan terampil dan ahli } \\
\text { dalam mengerjakan } \\
\text { pekerjaan yang sedang } \\
\text { dikerjakan }\end{array}$ \\
\hline 2 & $\begin{array}{c}\text { Kemampuan } \\
\text { tugas yang } \\
\text { tidak spesifik } \\
\text { pekerjaan }\end{array}$ & $\begin{array}{l}\text { Karwan mampu } \\
\text { mengoperasaikan alat-alat } \\
\text { elektronik seperti } \\
\text { komputer, dan lain-lain }\end{array}$ \\
\hline 3 & $\begin{array}{c}\text { Komunikasi } \\
\text { lisan dan } \\
\text { tertulis }\end{array}$ & $\begin{array}{l}\text { Mempunyai kepercayaan } \\
\text { diri untuk melakukan } \\
\text { komunikasi dengan antar } \\
\text { indvidu maupun } \\
\text { sekelompok orang }\end{array}$ \\
\hline 4 & $\begin{array}{l}\text { Menunjukan } \\
\text { usaha }\end{array}$ & $\begin{array}{l}\text { Karyawan berkomitmen } \\
\text { dan bersungguh-sungguh } \\
\text { dalam mengerjakan } \\
\text { pekerjaan sampai selesai }\end{array}$ \\
\hline 5 & $\begin{array}{l}\text { Memelihara } \\
\text { disiplin } \\
\text { pribadi }\end{array}$ & $\begin{array}{l}\text { Karyawan menyelesaikan } \\
\text { tugas dengan tepat waktu }\end{array}$ \\
\hline 6 & $\begin{array}{l}\text { Memfasilitasi } \\
\text { kinerja tim } \\
\text { dan rekan } \\
\text { kerja }\end{array}$ & $\begin{array}{l}\text { Dapat melakukan diskusi } \\
\text { dengan tim kerja untuk } \\
\text { memecahkan suatu masalah } \\
\text { dalam mencapai target dan } \\
\text { tujuan bersama }\end{array}$ \\
\hline 7 & Supervisi & $\begin{array}{l}\text { Karyawan } \\
\text { memahami/mengerti } \\
\text { tentang tugas-tugas yang } \\
\text { diberikan dan } \\
\text { mengerjakannya dengan } \\
\text { baik }\end{array}$ \\
\hline 8 & $\begin{array}{l}\text { Manajemen } \\
\text { dan } \\
\text { administrasi }\end{array}$ & $\begin{array}{l}\text { Mampu memahami } \\
\text { masalah dan } \\
\text { menyelesaikan/memberikan } \\
\text { keputusan bagi masalah } \\
\text { tersebut secara individu }\end{array}$ \\
\hline
\end{tabular}


Sumber: (Fahmi, 2016)

Berdasarkan hasil evaluasi terhadap variabel $\mathrm{X}$ dan Y tersebut di atas, maka diperoleh dilakukan uji validitas dan uji reliabilitas untuk mendapatkan data yang valid dan data yang menjawab konsistensi responden dalam menjawab kuisioner yang diberikan. Berikut hasil uji validitas dan reliabilitas yang diperoleh dari hasil penelitian:

\section{Uji Validitas}

Instrumen atau item yang valid berarti alat ukur yang digunakan untuk mendapatkan data adalah valid. Jika instrumen tersebut sudah valid, maka dapat dipergunakan untuk mengukur apa yang hendak diukur atau dicari dalam penelitian. Tetapi jika instrumen atau item-item kuesioner tersebut tidak valid berarti tidak dapat digunakan untuk mengukur.

a. Validitas Variabel Pelatihan (X)

Tabel 3

Validitas Variabel Pelatihan (X)

\begin{tabular}{llll}
\hline Item & r hitung & $\mathrm{r}$ table & Keterangan \\
\hline Pertanyaan 1 & 0,347 & 0,2638 & Valid \\
Pertanyaan 2 & 0,442 & 0,2638 & Valid \\
Pertanyaan 3 & 0,539 & 0,2638 & Valid \\
Pertanyaan 4 & 0,308 & 0,2638 & Valid \\
Pertanyaan 5 & 0,345 & 0,2638 & Valid \\
Pertanyaan 6 & 0,494 & 0,2638 & Valid \\
Pertanyaan 7 & 0,462 & 0,2638 & Valid \\
Pertanyaan 8 & 0,526 & 0,2638 & Valid \\
Pertanyaan 9 & 0,381 & 0,2638 & Valid \\
\hline
\end{tabular}

Sumber: Pengolahan dengan SPSS 22.0

Setelah diuji coba dengan menggunakan kuisioner, diperoleh hasil bahwa butir-butir pertanyaan dalam variabel pelatihan merupakan pernyataan yang valid. responden menjawab dengan baik pertanyaan yang diberikan dan menghasilkan $r$ hitung yang lebih besar dari $r$ tabel. Hal ini menyatakan bahwa pernyataan yang telah valid dapat digunakan sebagai instrumen dalam penelitian selanjutnya.

b. Validitas Variabel Kinerja Karyawan (Y)

Tabel 4

Validitas Variabel Kinerja Karyawan

\begin{tabular}{llll}
\hline Item & $r$ hitung & $\mathrm{r}$ table & Keterangan \\
\hline
\end{tabular}

\begin{tabular}{llll}
\hline Pertanyaan 1 & 0,253 & 0,2638 & Valid \\
Pertanyaan 2 & 0,301 & 0,2638 & Valid \\
Pertanyaan 3 & 0,313 & 0,2638 & Valid \\
Pertanyaan 4 & 0,259 & 0,2638 & Valid \\
Pertanyaan 5 & 0,564 & 0,2638 & Valid \\
Pertanyaan 6 & 0,584 & 0,2638 & Valid \\
Pertanyaan 7 & 0,360 & 0,2638 & Valid \\
Pertanyaan 8 & 0,515 & 0,2638 & Valid \\
\hline
\end{tabular}

Sumber: Pengolahan dengan SPSS 22.0

Berdasarkan tabel 4 , pertanyaan yang diajukan dalam variabel $\mathrm{Y}$, yaitu hal yang berkenaan dengan kinerja menghasilkan semua jawaban yang valid, yaitu pertanyaan dapat dijawab dengan baik oleh responden. Hal ini menyatakan bahwa pernyataan yang telah valid dapat digunakan sebagai instrumen dalam penelitian selanjutnya.

\section{Konsistensi Jawaban}

Kriteria pengujian reliabilitas dilakukan dengan melihat koefisien Cronbach's Alpha. Pengujian ini merupakan ukuran suatu kestabilan dan konsistensi responden dalam menjawab hal yang berkaitan dengan pertanyaan yang disusun dalam suatu bentuk kuisioner. Berikut tabel yang digunakan untuk melihat konsistensi responden dala menjawab pertanyaan yang diberikan.

Tabel 5.

Interprestasi Konsistensi Jawaban

Nilai Reliabilitas Interprestasi

\begin{tabular}{ll}
\hline $0,8000-1,0000$ & Sangat tinggi \\
$0,6000-0,7999$ & Tinggi \\
$0,4000-0,5999$ & Sedang/cukup \\
$0,2000-0,3999$ & Rendah \\
$0,0000-0,1999$ & Sangat rendah
\end{tabular}

Sumber: (Sujarweni, 2015)

a. Konsistensi Jawaban Responden Terhadap Pertanyaan Variabel Pelatihan (X)

Data yang sudah diperoleh, selanjutnya diproses dengan perhitungan uji konsistensi pada variabel pelatihan $(\mathrm{X})$. Berdasarkan penilaian melalui software SPSS 22.0, Cronbach's Alpha telah menghasilkan nilai reliabilitas 0,749 (Tabel 4.). Dari nilai tersebut telah menunjukan bahwa variabel pelatihan $(\mathrm{X})$ memiliki nilai interprestasi tinggi, yaitu pada rentang 0,60000,7999 . Maka instrumen penelitian pada variabel pelatihan $(\mathrm{X})$ dapat dinyatakan reliabel atau responden konsisten dan stabil dalam menjawab pertanyaan yang diajukan di dalam kuisioner.

ISSN: 2355-0295, e-ISSN: 2549-8932

http://ejournal.bsi.ac.id/ejurnal/index.php/ecodemica 
Berikut hasil uji reliabilitas variabel pelatihan dalam bentuk tabel:

Tabel 6.

Konsistensi Variabel Pelatihan

\begin{tabular}{llll}
\hline $\begin{array}{l}\text { Varia } \\
\text { bel }\end{array}$ & $\begin{array}{l}\text { Cronba } \\
\text { ch's } \\
\text { Alpha }\end{array}$ & $\begin{array}{l}\text { Interprestas } \\
\text { R }\end{array}$ & Reliabilitas \\
\hline $\begin{array}{l}\text { Pela } \\
\text { tihan }\end{array}$ & 0,749 & $\begin{array}{l}0,50 \leq \mathrm{r} \leq \\
0,79\end{array}$ & $\begin{array}{l}\text { Korelasi } \\
\text { Sedang Secara } \\
\text { Positif }\end{array}$ \\
\hline
\end{tabular}

Sumber: Pengolahan dengan SPSS 22.0

b. Konsistensi Jawaban Responden terhadap

Pertanyaan Variabel Kinerja Karyawan (Y)

Sama halnya dengan variabel pelatihan (X), variabel kinerja karyawan (Y) juga diproses dengan perhitungan uji Konsistensi. Berdasarkan penilaian melalui software SPSS 22.0, Cronbach's Alpha menghasilkan nilai reliabilitas 0,704. Berdasarkan table interpretasi konsistensi variabel kinerja karyawan (Y) memiliki nilai interprestasi tinggi, yaitu pada rentang 0,6000-0,7999. Maka instrumen penelitian pada variabel pelatihan (X) dapat dinyatakan reliabel atau responden menjawab pertanyaan secara konsisten dan stabil terhadap pertanyaan yang diberikan didalam kuisioner. Berikut hasil uji reliabilitas variabel pelatihan dalam bentuk tabel:

Tabel 7
Konsistensi Variabel Kinerja Karyawan

berdasarkan tabel kekuatan korelasi, nilai 0,338 berada pada rentang $0,20-0,399$.

Tingkat signifikansi berdasarkan Tabel 6. di atas adalah bernilai 0,033 menyatakan lebih kecil dari pada $0,1(0,033<0,1)$. Maka keputusannya adalah Ho ditolak dan Ha diterima.

Sumber: Pengolahan dengan SPSS 22.0

Dengan demikian, dinyatakan bahwa pelatihan yang diberikan oleh PT. Bank Bukopin Tbk kepada karyawan memberikan pengaruhnya terhadap kinerja karyawan tersebut.

Tabel 8

Korelasi

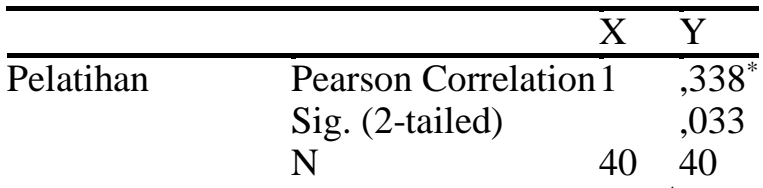

Kinerja KaryawanPearson Correlation, 338*1

$\begin{array}{ll}\text { Sig. (2-tailed) } & , 033 \\ \mathrm{~N} & 40 \quad 40\end{array}$

Uji Penekanan Hubungan variabel Dependen dan Independen

Uji ini merupakan uji lanjutan, yaitu uji Hipotesis Simultan dengan menggunakan Uji Anova atau uji F. Uji ini digunakan untuk menekankan hubungan variabel dependen dan independen. Menguatkan uji korelasi yang telah

\begin{tabular}{lll}
\hline Variabel & Cronbach's Alpha & Interprest \\
\hline Kinerja Karya wan & 0,704 & $0,50 \leq \mathrm{r} \leq$
\end{tabular}

Sumber: Pengolahan dengan SPSS 22.0

3. Hasil Evaluasi Pengaruh Pelatihan terhadap kinerja karyawan

Berdasarkan hasil validitas dan konsistensi yang diperoleh di atas, maka langkah Selanjutnya adalah mencari koefisien korelasi yang bertujuan untuk mengetahui besar kecilnya hubungan antara variabel dependen terhadap variabel independen. Untuk melihat korelasi antara variabel pelatihan dengan variabel kinerja, berikut tabel hasil perhitungannya:

Dari hasil perhitungan dengan menggunakan SPSS 22.0 (Tabel 8) diketahui bahwa korelasi antara variabel pelatihan dengan variabel kinerja karyawan diperoleh nilai koefisien korelasi sebesar 0,338. Yang berarti korelasi hubungan antara variabel $\mathrm{X}$ dan $\mathrm{Y}$ lemah karena

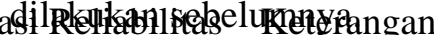

Tabel 9.

ANOVA $^{\mathrm{a}}$

\begin{tabular}{lllll}
\hline & Sum & of & Mean & \\
Model & Squares & DfSquare & F & Sig. \\
\hline 1Regression64,391 & 164,391 & $4,890,033^{b}$ \\
Residual & 500,384 & 3813,168 & \\
Total & 564,775 & 39 & & \\
\hline
\end{tabular}

Sumber: Pengolahan dengan SPSS 22.0

Penggunaan uji anova atau $\mathrm{F}$ test untuk melakukan hipotesis secara simultan antara variabel $\mathrm{X}$ (pelatihan) terhadap variabel $\mathrm{Y}$ (kinerja karyawan) dengan membandingkan antara nilai $\mathrm{f}$ hitung (f0) dengan $\mathrm{f}$ tabel (f nilai kritis).

Berdasarkan hasil uji Anova yang diperoleh, dapat diketahui bahwa $\mathrm{F}$ hitung $>\mathrm{F}$ tabel yang didapat adalah 4,890 > 2,84 atau dengan melihat tingkat sig.F lebih kecil dari pada 0,1 yaitu 0,033 
$<0,1$. Maka keputusannya adalah Ho ditolak dan Ha diterima, dimana:

Ha: Terdapat pengaruh pelatihan terhadap kinerja karyawan

Ho: Tidak terdapat pengaruh pelatihan terhadap kinerja Karyawan

Dengan menggunakan uji Anova pun diperoleh hasil bahwa variabel $\mathrm{X}$ yang terdiri atas kemampuan karyawan, sikap dan mental karyawan, kerjasama, perilaku karyawan, loyalitas karyawan, jenang karir, dan pengetahuan memberikan pengaruh terhadap variabel $\mathrm{Y}$ yang terdiri atas kemampuan tugas spesifik dan tidak spesifik, komunikasi, usaha meningkatkan diri, kedisiplinan, motivasi, supervisi, dan manajemen administrasi karyawan.

Pelatihan akan menciptakan karyawan yang mampu berprestasi untuk suatu instansi dalam gerakan masa depan. Pentingnya pelatihan bukan hanya bagi karyawan yang bersangkutan, tetapi juga keuntungan PT. Bank Bukopin, karena dengan meningkatnya kemampuan atau keterampilan karyawan, dapat meningkatkan kinerja kerja para karyawan. Kinerja yang meningkat berarti organisasi yang bersangkutan akan memperoleh keuntungan. Pelatihan juga merupakan upaya untuk mengembangkan kemampuan intelektual dan kepribadian karyawan. Oleh karena itu, setiap organisasi yang ingin berkembang, harus mengembangkan sumber daya manusianya, salah satunya dengan mengadakan pelatihan sehingga dapat meningkatkan kinerja karyawan tersebut.

Persamaan Regresi

Tabel 10

Regresi Sederhana

Unstandardized Standardize

Coefficients Coefficients

\begin{tabular}{|c|c|c|c|}
\hline \multirow[b]{2}{*}{ Model } & & & \multirow[b]{2}{*}{$\mathrm{T} \quad$ Sig. } \\
\hline & B & Error & \\
\hline 1.Constant & 19,544 & 4,729 & $4,133,000$ \\
\hline$\overline{\mathrm{Y}}$ & ,396 & $\begin{array}{ll}, 179 & 338\end{array}$ & $2,211,033$ \\
\hline
\end{tabular}

Sumber: Pengolahan dengan SPSS 22.0

Pada tabel regresi sederhana (tabel 10) tersebut memperlihatkan bahwa kolom constant (a) memiliki angka 19,544, sedangkan nilai variabel Y (b) 0,396 yang terdapat pada kolom B, jika dimasukkan kedalam rumus persamaan regresi:

$$
Y=19,544+0,396 X
$$

Nilai constant 19,544 menyatakan bahwa jika tidak ada pelatihan, maka kinerja karyawan adalah 19,544. Koefisien regresi sebesar 0,396 yang menyatakan bahwa setiap penambahan $1 \%$ pelatihan akan meningkatkan kinerja karyawan sebesar 0,396. Namun sebaliknya jika pelatihan akan turun $1 \%$ maka kinerja karyawan akan berkurang 0,396. Hal ini menunjukkan bahwa tanda positif menyatakan arah hubungan searah, dimana kenaikan atau penurunan variabel pelatihan (dependen) dapat mempengaruhi kenaikan atau penurunan variabel kinerja karyawan (independen). Karena nilai signifikansi 0,033 lebih kecil dari 0,1 (0,033 < $0,1)$, maka keputusannya adalah H0 ditolak dan Ha diterima, dimana:

Ha: Terdapat pengaruh pada pelatihan terhadap kinerja karyawan

H0: Tidak terdapat pengaruh pada pelatihan terhadap kinerja Karyawan

\section{PENUTUP}

Berdasarkan hasil penelitian yang dilakukan, dapat dinyatakan bahwa pelatihan memiliki hubungan yang positif, namun dengan tingkat korelasi rendah dan memiliki pengaruh yang signifikan dan positif terhadap kinerja karyawan dengan nilai sebesar 33,8\%. Dilihat dari beberapa hasil analisis, yaitu analisis korelasi didapatkan hasil analisis uji anava diperoleh $\mathrm{F}$ hitung > F tabel yang didapat adalah 4,890 > 2,84 atau dengan melihat tingkat sig.F lebih kecil dari pada 0,1 yaitu $0,033<0,1$. Maka keputusannya adalah yaitu terdapat pengaruh pelatihan terhadap kinerja karyawan, dan pernyataan ini diperkuat dengan hasil uji regresi linier sederhana menunjukkan nilai koefisien beta bernilai positif.

Kesadaran karyawan akan pentingnya pelatihan, maka PT. Bank Bukopin hendaknya melaksanakan pelatihan dilakukan secara berkelanjutan. Dan dengan adanya pemberian pelatihan bagi karyawan, maka diharapkan karyawan tersebut dapat melakukan kinerja yang maksimal bagi perusahaan.

Bagi peneliti selanjutnya, penelitian ini dapat dikembangkan dengan menambahkan atau mencari variabel lain untuk mengetahui faktor yang benar-banar menjadi acuan peningkatan kinerja karyawan.

$$
Y=a+b X
$$




\section{REFERENSI}

Fahmi, I. (2016). Pengantar Manajemen Sumber Daya Manusia Konsep dan Kinerja. (R. Fachruddin, Ed.) (Pertama). jakarta.

Fibriany, F. W. (2017). Peningkatan Produktivitas Melalui Pelatihan Karyawan, $X V I I(2), \quad 165-170 . \quad$ Retrieved from http://ejournal.bsi.ac.id/ejurnal/index.php/ cakrawala/article/view/2167/1760

Hartati, T., \& Amir, H. (2016). Pengaruh Pelatihan Kerja Terhadap, 13(1), 13-20. Retrieved from http://jurnal.pnj.ac.id/index.php/epigram/a rticle/download/805/513

Jayanthi, Y. D., \& Cahyana, A. (2014). Pengaruh Hasil Pelatihan Terhadap Kinerja Karyawan di Balai Pelatihan Manajerial PT. KAI Bandung. Jurnal Pendidikan Luar Sekolah, 10, 1-12. Retrieved from http://ejournal.upi.edu/index.php/pls/articl e/view/5410/3706

Prasetyo, A. I., \& Relawan, I. N. (2017). Ecodemica. Jurnal Ecodemica: Jurnal Ekonomi, Manajemen, Dan Bisnis, 1(1), 107-117. Retrieved from http://ejournal.bsi.ac.id/ejurnal/index.php/ ecodemica/article/view/1553/pdf

Sedarmayanti. (2016). Manajemen Sumber Daya Manusia, Reformasi Birokrasi dan Manajemen Pegawai Negeri Sipil. (D. Sumayyah, Ed.) (Revisi). jakarta: Refika Aditama.

Sujarweni, V. W. (2015). SPSS untuk Penelitian. (Florent, Ed.). Yogyakarta: Penerbit Pustaka Baru Press.

Wibowo. (2017). Manajemen Kinerja (Kelima). Depok: RajaGrafindo Persada.

\section{PROFIL PENULIS}

Firstianty Wahyuhening Fibriany, S. TP, MM. Lahir di Jakarta pada tanggal 24 Februari 1978. Penulis tamat pendidikan Strata satu dari IPB Jurusan Teknik Industri Pertanian tahun 2000 dengan menyandang gelar Sarjana Teknologi Pertanian (S. TP) dan menamatkan pendidikan Strata Dua di MMA IPB sekarang SB IPB dengan menyandang gelar Magister Manajemen (MM) pada tahun 2003. Tahun 2000 sampai dengan tahun 2004 penulis bekerja sebagai HRD di perusahaan swasta nasional. Sejak tahun 2010 menjadi dosen tetap pada Akademi Bina Sarana Informatika sekarang menjadi Universitas BSI pada jurusan Manajemen Informatika.

Nur Hani Oktaviani, Lahir di Jakarta pada bulan Okotber. Penulis telah menyelesaikan perkuliahannya di Universitas Bina Sarana Informatika pada jurusan Manajemen Bisnis. Saat ini penulis telah bekerja di BPN Jakarta Utara. 